\title{
Healthcare professionals and Basic Knowledge of Medications in Saudi Arabia
}

\author{
Yousef Ahmed Alomi ${ }^{1, *}$, Dima Ahmad Alaskari², Malak Mohammad Almelfi², Dima Ali Badawi ${ }^{3}$, \\ Abdullah Mohammad Alshihri ${ }^{4}$ \\ ${ }^{1}$ The Past General Manager of General Administration of Pharmaceutical Care and The Past Head, National Clinical pharmacy \\ and pharmacy practice and Pharmacy $R$ and D Administration, Ministry of Health, Riyadh, KSA. \\ ${ }^{2}$ General Administration of Pharmaceutical Care, Ministry of Health, Riyadh, SAUDI ARABIA. \\ ${ }^{3}$ Pharmaceutical Care Services, Saudi Germany Hospital, Aseer, SAUDI ARABIA. \\ ${ }^{4}$ Head, Pharmaceutical Care Services, Abha Maternity and Children Hospital, Abha, SAUDI ARABIA.
}

Received: 02 June 2018;

Accepted: 28 August 2018

*Correspondence to:

Dr. Yousef Ahmed Alomi,

The Past General Manager of General Administration of Pharmaceutical Care The Past Head, National Clinical pharmacy and pharmacy practice

Head, Pharmacy $R$ and $D$ Administration Ministry of Health, P.O.BOX 100, Riyadh 11392, Riyadh, SAUDI ARABIA.

Email:yalomi@gmail.com

Copyright: (C) the author(s),publisher and licensee Indian Academy of Pharmacists. This is an open-access article distributed under the terms of the Creative Commons Attribution Non-Commercial License, which permits unrestricted non-commercial use, distribution, and reproduction in any medium, provided the original work is properly cited.

\begin{abstract}
Objective: To explore the Healthcare professionals and Basic Knowledge of Medications in Saudi Arabia. Methods: It is a 4-months cross-sectional survey of healthcare professionals and knowledge of medicines. The survey consisted of two-part, demographic information and second part forty-nine questions divided into four domains. It included domain one: Primary or essential information about healthcare providers medication, domain two: healthcare professionals information about the drug-related problem, domain three: healthcare professionals information about drug-related cost and domain four: Healthcare providers perception of medications. All type of healthcare professionals included in the study. Medline Plus health information and DailyMed-INH elements information from National Institute of Health United State of America were used. The survey was distributed through social media by using what's App to more than one thousand healthcare professionals overall Kingdom of Saudi Arabia. The survey was made in an electronic format and it analyzed domain one Primary or necessary information about healthcare professionals medication through survey monkey system. Results: The total responders were (188) Healthcare professionals. Of those 177 (95.16\%) were Saudi and 9 (4.84\%) were non-Saudi. The gender distribution 120 (63.83\%) were females and 68 (36.17\%) were males. The most of Healthcare professionals were pharmacists $93(71.54 \%)$, followed by nurses $18(13.85 \%)$ and physicians $15(11.54 \%)$. The most type of medications used was anti-hypertension medicines, anti-diabetic medicines, Skin medications and drugs for Respiratory Diseases. The healthcare professionals showed adequate knowledge both complete and incomplete information of the generic name of Medicines $117(67.6 \%)$, the trade name $126(73.7 \%)$, drug strength 128 (73.9\%) and dosage form of medication $132(76.7 \%)$. The responders showed adequate knowledge about medications with both complete information and incomplete information about drug indication 159 (85.5\%), how to use medications 161 (87\%). The administration time 161 (86.55\%), what to do if patient forgot one dose $133(71.9 \%)$, the potential to adhere medication $159(86.4 \%)$ and the time to stop drugs $148(79.57 \%)$. The majority of responders used drug bulletin 126 (69.61\%), Health practitioners 123 (67.96\%), Internet 108 (59.67\%) and Drug Information Center at the hospital 36 (19.89\%) as sources of drug information. Conclusion: More than one-third of Healthcare professionals missed complete essential drug information knowledge. Targeting of health care professionals; with individual basic drug information courses for the healthcare professionals through drug information services is required in Saudi Arabia.
\end{abstract}

Key words: Healthcare professional, Knowledge, Medications, Ministry of Health, Saudi Arabia.

\section{INTRODUCTION}

The drug distribution system passes through several processes until reach to the patient. Procurement, storage, prescribing, preparation, dispensing, administration and follow up stage. ${ }^{[1-3]}$ Each stage needs particular medication information and knowledge to an accomplishment the stage. The healthcare provisional must familiur with the basic principles for each drug; precautions for preparation; and considerations concerning administration to patients. Errors may occur by either lack of knowledge, insufficient practical skills or because of an accidental happening. The most type of healthcare professionals dealt with those stages and contact with patients are a physician, pharmacist and nurses. Other type healthcare professionals less contact with medications. Several studies investigated the actual level of primary knowledge of medication of healthcare professionals including a physician, pharmacist and nurses. ${ }^{[-5]}$ Each study discussed one type alone. There is variation between the types of healthcare professionals among medication knowledge with different specialties. However, it seldom to find study in Saudi Arabia or Gulf and Middle East counties discussed general primary medications knowledge. ${ }^{[6]}$ The objective of the instigation is to explore healthcare professional primary knowledge about medication in Kingdom of Saudi Arabia. 


\section{METHODS}

It is a 4-months cross-sectional survey of healthcare professionals and knowledge of medicines. The survey consisted of two-part demographic information and second part forty-nine questions divided into four domains. It included domain one: Primary or essential information about healthcare providers medication, domain two: healthcare professionals information about the drug-related problem, domain three: healthcare professionals information about drug-related cost and domain four: Healthcare providers perception of medications. All type of healthcare professionals included in the study. Medline Plus health information and DailyMed-INH elements information from National Institute of Heath United State of America were used. ${ }^{[2-3]}$ The 5 -point Likert response scale system used. The questions were open and closed-ended. The survey distributed through social media by using what's App to more than one thousand healthcare professionals overall Kingdom of Saudi Arabia. A messages reminders sent to healthcare professional after two weeks and additional messages reminders sent to healthcare professional after four weeks The survey made an electronic format and it analyzed domain one Primary or necessary information about healthcare professionals medication through survey monkey system.

\section{RESULTS}

The total responders were (188) Healthcare professionals. Of those 177 $(95.16 \%)$ were Saudi and $9(4.84 \%)$ were non-Saudi. The gender distribution $120(63.83 \%)$ was female and $68(36.17 \%)$ was male. The majority of them in age (18-44) 86.7\% and located at Asir region 89 (47.34\%) and Riyadh region $46(24.5 \%)$. The most of Healthcare professionals were pharmacist 93 (71.54\%), followed by nurses 18 (13.85\%) and physicians 15 (11.54\%). The most responders qualifications had the Bachelor Degree 126 (67.02\%) followed by Diploma 33 (17.55\%) and Master degree $22(11.7 \%)$ The most type of medications used was anti-hypertension medicines, antidiabetic medicines, Skin medications and drugs for Respiratory Diseases. Also, the most number of medication taken either one $29(15.85 \%)$ or two medication $17(9.29 \%)$ as explores by Table 1 . The healthcare professionals showed acceptable knowledge both complete and incomplete information the generic name of Medicines 117 (67.6\%), the trade name 126 (73.7\%), drug strength $128(73.9 \%)$ and dosage form of medication $132(76.7 \%)$ as explored in Table2. The responders showed adequate knowledge about medications with both complete information and incomplete information about drug indication 159 (85.5\%) and how to use medications 161 (87\%). The administration time 161 (86.55\%), what to do if patient forgot one dose $133(71.9 \%)$, the potential to adhere medication $159(86.4 \%)$ and the time to stop drugs $148(79.57 \%)$ as explored in Table 3. The majority of responders used drug bulletin 126 (69.61\%), Health practitioners 123 (67.96\%), Internet $108(59.67 \%)$ and Drug Information Center at the hospital $36(19.89 \%)$ as sources of drug information as explored in Table 4.

\section{DISCUSSION}

The pharmacy administration at Ministry of Health stated more than thirty pharmacy practice and clinical pharmacy program during the past Pharmacy plan $^{[7]}$ which had led to improvement in pharmacy services offered to the patient, with preventing drug-related morbidities and mortality and avoidance of the economic burden on the healthcare system. The program consisted of medications information and knowledge designed through guidelines or protocol of disease management. ${ }^{[8]}$ The primary job of that program was distributions of medications knowledge or information. The most example of the programs was medication safety program, national drug information centers, evidence-based therapeutic guidelines, pain management services and anticoagulation program. ${ }^{[9-12]}$ The majority of the services involved the primary corner element as pharmacists with additional healthcare care professionals like the physicians and nurses. The question

\begin{tabular}{|c|c|c|}
\hline Characteristics & Response N & Response \% \\
\hline \multicolumn{3}{|l|}{ Sex } \\
\hline Female & 120 & $63.83 \%$ \\
\hline Male & 68 & $36.17 \%$ \\
\hline \multicolumn{3}{|l|}{ Nationality } \\
\hline Saudi & 177 & $95.16 \%$ \\
\hline Non-Saudi & 9 & $4.84 \%$ \\
\hline Answered question & 186 & $100 \%$ \\
\hline Skipped question & 2 & \\
\hline \multicolumn{3}{|l|}{ Age } \\
\hline$<18$ & 5 & $2.66 \%$ \\
\hline $18-29$ & 112 & $59.57 \%$ \\
\hline $30-44$ & 51 & $27.13 \%$ \\
\hline $45-59$ & 19 & $10.11 \%$ \\
\hline $60+$ & 1 & $0.53 \%$ \\
\hline \multicolumn{3}{|l|}{ Healthcare professional } \\
\hline Doctor & 15 & $11.54 \%$ \\
\hline Dentist & 4 & $3.08 \%$ \\
\hline Pharmacist & 93 & $71.54 \%$ \\
\hline Nurse & 18 & $13.85 \%$ \\
\hline Others & 33 & $25.38 \%$ \\
\hline Answered question & 130 & \\
\hline Skipped question & 58 & \\
\hline \multicolumn{3}{|l|}{ Total Experiences } \\
\hline Doctorate degree & 7 & $3.72 \%$ \\
\hline Master degree & 22 & $11.70 \%$ \\
\hline Bachelor Degree & 126 & $67.02 \%$ \\
\hline Diploma & 33 & $17.55 \%$ \\
\hline High school & 7 & $3.72 \%$ \\
\hline Intermediate School & 0 & $0.00 \%$ \\
\hline Primary School & 0 & $0.00 \%$ \\
\hline Not educated & 0 & $0.00 \%$ \\
\hline Answered question & 188 & $100 \%$ \\
\hline Skipped question & 0 & \\
\hline \multicolumn{3}{|l|}{ The current medications } \\
\hline Diabetic Medication & 26 & $13.83 \%$ \\
\hline Antihypertensive Medication & 28 & $14.89 \%$ \\
\hline Cardiac Medication & 7 & $3.72 \%$ \\
\hline Asthma Medication & 16 & $8.51 \%$ \\
\hline Derma Medication & 18 & $9.57 \%$ \\
\hline Anti-Rheumatic & 13 & $6.91 \%$ \\
\hline Do not take anything now & 125 & $66.49 \%$ \\
\hline Others & 27 & $14.36 \%$ \\
\hline \multicolumn{3}{|c|}{ Number of current medication taken } \\
\hline Nothing & 121 & $66.12 \%$ \\
\hline 1 & 29 & $15.85 \%$ \\
\hline 2 & 17 & $9.29 \%$ \\
\hline 3 & 7 & $3.83 \%$ \\
\hline 4 & 2 & $1.09 \%$ \\
\hline 5 & 2 & $1.09 \%$ \\
\hline 6 & 2 & $1.09 \%$ \\
\hline 7 & 3 & $1.64 \%$ \\
\hline 8 & 0 & $0.00 \%$ \\
\hline 9 & 0 & $0.00 \%$ \\
\hline 10 & 0 & $0.00 \%$ \\
\hline more than 10 & 0 & $0.00 \%$ \\
\hline Answered question & 183 & \\
\hline Skipped question & 5 & \\
\hline
\end{tabular}


Alomi, et al.: Study about medications knowledge among healthcare professionals

Table 2: General Information of used medication.

\begin{tabular}{|l|l|l|l|l|l|l|l|l|} 
No. & $\begin{array}{l}\text { Answer } \\
\text { Options }\end{array}$ & $\begin{array}{l}\text { Complete } \\
\text { information }\end{array}$ & $\begin{array}{l}\text { Incomplete } \\
\text { information }\end{array}$ & $\begin{array}{l}\text { Weak } \\
\text { information }\end{array}$ & $\begin{array}{l}\text { do not } \\
\text { have this } \\
\text { information }\end{array}$ & $\begin{array}{l}\text { does not } \\
\text { need this } \\
\text { information }\end{array}$ & $\begin{array}{l}\text { Rating } \\
\text { Average }\end{array}$ \\
\hline 1 & The generic name & 86 & 31 & 19 & 16 & 21 & 3.84 & 173 \\
\hline 2 & The trade name & 86 & 40 & 16 & 10 & 19 & 3.96 & 171 \\
\hline 3 & The drug strength & 86 & 42 & 15 & 12 & 18 & 3.96 & 173 \\
\hline 4 & Dosage form & 111 & 21 & 14 & 8 & 18 & 4.16 \\
\hline
\end{tabular}

\begin{tabular}{|c|c|c|c|c|c|c|c|c|}
\hline No. & Answer Options & $\begin{array}{l}\text { Complete } \\
\text { information }\end{array}$ & $\begin{array}{l}\text { Incomplete } \\
\text { information }\end{array}$ & $\begin{array}{l}\text { Weak } \\
\text { information }\end{array}$ & $\begin{array}{l}\text { do not } \\
\text { have this } \\
\text { information }\end{array}$ & $\begin{array}{l}\text { does not } \\
\text { need this } \\
\text { information }\end{array}$ & $\begin{array}{l}\text { Rating } \\
\text { Average }\end{array}$ & Response N \\
\hline 1 & Drug Indication & 121 & 38 & 6 & 3 & 18 & 4.30 & 186 \\
\hline 2 & $\begin{array}{l}\text { How to use the } \\
\text { medications }\end{array}$ & 142 & 19 & 4 & 2 & 18 & 4.43 & 185 \\
\hline 3 & $\begin{array}{l}\text { Medication administration } \\
\text { time }\end{array}$ & 142 & 19 & 2 & 5 & 18 & 4.41 & 186 \\
\hline 4 & $\begin{array}{l}\text { What to do if I forgot one } \\
\text { dose }\end{array}$ & 97 & 36 & 13 & 20 & 19 & 3.93 & 185 \\
\hline 5 & $\begin{array}{l}\text { Adherence to medication } \\
\text { and it is important }\end{array}$ & 136 & 23 & 3 & 5 & 17 & 4.39 & 184 \\
\hline 6 & The time to stop treatment & 114 & 34 & 7 & 15 & 16 & 4.16 & 186 \\
\hline
\end{tabular}

\section{Table 4: Drug Information sources.}

\begin{tabular}{|l|l|l|}
\hline patient trust & Response N & Response \% \\
\hline Answer Options & 123 & $67.96 \%$ \\
\hline Health practitioners & 126 & $69.61 \%$ \\
\hline Drug Bulletin & 24 & $13.26 \%$ \\
\hline Relatives and friends & 108 & $59.67 \%$ \\
\hline The Internet & 36 & $19.89 \%$ \\
\hline Drug Information Center at the hospital & 22 & $12.15 \%$ \\
\hline lectures in hospital & 9 & $4.97 \%$ \\
\hline Lectures in health center & 12 & $6.63 \%$ \\
\hline Drug education in markets Exhibition & 17 & $9.39 \%$ \\
\hline Other (please specify) & \\
\hline answered question: 181 and skipped question: 7 & \\
\hline
\end{tabular}

raised does indeed need to establish those programs. Does that need to include the physicians or nurses? What is the actual demand for medication knowledge from those programs? The investigator tried to explore the primary medications knowledge of the healthcare care professionals in Kingdom of Saudi Arabia. The finding of the study showed that healthcare care professionals had acceptable primary knowledge of medications that have included generic names, trade name, drug strength, dosage forms. That is typical finding because most responders were a pharmacist with adequate medications knowledge. Also, there are medication safety courses delivered to all physician and nurses through pharmacy and some of the hospital had computerized order entry that helps all healthcare care professionals to remember the primary knowledge of medications. The results of dose strength almost resemble what has reported by Simonsen B et al. of nursing knowledge of medications, other healthcare professionals could not compare with them because no study exists about knowledge of medications. ${ }^{[5]}$ The others finding of a study of knowledge of medications indication, usage of medications, administration times, the instruction if medications missed by the patient, drug compliance and duration of therapy is right knowledge of medications and better than a generic name, trade name, drug strength and dosage forms. That expected because most of healthcare professionals education the patient with that information and rarely mentioned drug name or strength. Also, the daily practice information deal with that information with the medical team to prevent any medications related problems may occur in the patients. The finding of Administration time is better that's what reported by Jodlowski $\mathrm{T}$ et al. because the majority of medications were anti-hypertensive and anti-diabetic medications more popular and common usage in the comparative study as Antiretroviral medications. ${ }^{[13]}$ Others finding with healthcare professionals does not exist in the studies. The finding of sources of medications knowledge of healthcare professionals was Drug bulletin and internet with deficient percentage of drug information centers that is due to drug leaflet and internet more natural way to get the medications knowledge and especially with more usage of the new technology of mobile devices. Also most of the healthcare professionals are familiar with drug information services in the hospital or take time to answer the question or the healthcare professionals though that is is comfortable and does not bother the drug information centers to get the information and prefer to ask the complicated inquiries. Our finding is different from Salhia $\mathrm{H}$ et al. report about the generic medications and most of the physicians get the information from a medical representative. Because the general information about medications is more common and very easy to get them from drug bulletin or through the internet and more common and more accessible than the generic medications available in the countries, so they need information from the manufacturer. ${ }^{[6]}$ The healthcare professionals had proper medications knowledge with missed some elements, the sources of information need more education to healthcare professionals to choose the appropriate resources of drug information with an emphasis on awareness of drug information services in the hospitals is highly recommended. 


\section{CONCLUSION}

The Healthcare professionals missed some essential drug information knowledge. The healthcare professional's demand for basic drug information courses including medication safety and awareness of drug information services at Ministry of Health hospital in Kingdom of Saudi Arabia.

\section{ACKNOWLEDGMENT}

None

\section{CONFLICT OF INTEREST}

None

\section{ABBREVIATIONS}

KSA: Kingdom of Saudi Arabia; MOH: Ministry of Health; CBAHI: Saudi Center for Accreditation of Healthcare Institutions.

\section{REFERENCES}

1. Pedersen C, Pharm, Schneider P, Scheckelhoff D, Pedersen. ASHP national survey of pharmacy practice in hospital settings: Prescribing and transcribing-2016. Am J Heal Syst Pharm. 2017;74(17):411-27.

2. Pedersen CA, Schneider PJ, Scheckelhoff DJ. ASHP national survey of pharmacy practice in hospital settings: Monitoring and patient education-2015. Am J Heal Pharm. 2016;73(17):1307-30.

3. Pedersen CA, Schneider PJ, Scheckelhoff DJ. ASHP national survey of pharmacy practice in hospital settings: Dispensing and administration - 2014. Am J Heal
Pharm. 2015;72(13):1119-37.

4. West CP, Shanafelt TD, Kolars JC. Quality of Life, Burnout, Educational Debt and Medical Knowledge Among Internal Medicine Residents. JAMA. 2011;306(9).

5. Simonsen BO, Daehlin GK, Johansson I, Farup PG. Differences in medication knowledge and risk of errors between graduating nursing students and working registered nurses: a comparative study. BMC Health Serv Res. 2014;14(1):580.

6. Salhia HO, Ali A, Rezk NL, El Metwally A. Perception and attitude of physicians toward local generic medicines in Saudi Arabia: A questionnaire-based study. Saudi Pharm J. 2015;23(4):397-404.

7. Alomi YA, Alghamdi SJ, Alattyh RA. Strategic Plan of General Administration of Pharmaceutical Care at Ministry of Health in Saudi Arabia 2012-2022. J Pharm Pharm Sci 2015;1(3):1-8.

8. Al-Hameed FMFM, Al-Dorzi HMHM, Abdelaal MAMA, Alaklabi A, Bakhsh E, Alomi YAYA, et al. The Saudi clinical practice guideline for the prophylaxis of venous thromboembolism in medical and critically ill patients. Saudi Med J. 2016;37(11).

9. Alomi YA. National Medication Safety Program at Ministry of Health in Saudi Arabia. J Pharmacol Clin Res. 2017;3(2):1-7.

10. YAA. National Drug Information Center Program at Ministry of Health in Saudi Arabia. Adv Pharmacoepidemiol Drug Saf. 2016;5(1):1-2.

11. Alomi YA. National Pharmacy Pain Management Program at Ministry of Health in Saudi Arabia. J Pharmacol Clin Res. 2017;3(2).

12. Ahmed $Y$, Pharm A, Pharm C. National Pharmacy Practice Programs at Ministry of Health in Saudi Arabia. 2015;1(2):17-8.

13. Jodlowski TZ, Sym D, Conry J, Kanmaz T. Antiretroviral medication knowledge among New York State pharmacists: room for improvement. J Pharm Pract. 2010;23(5):507-10.

Cite this article as: Alomi YA, Alaskari DA, Almelfi MM, Badawi DA, Alshihri AM. Healthcare professionals and Basic Knowledge of Medications in Saudi Arabia. J Pharm Pract Community Med. 2018;4(3):167-70. 